\title{
Prevalence and Intensity of Economically Important Fungal Diseases of Sorghum in South Tigray, Ethiopia
}

\author{
Teklay Abebe Teferi", Muruts Legesse Wubshet
}

TARI, Alamata Agricultural Research Centre, Alamata, Ethiopia

Email address:

teklayabebe6@gmail.com (T. A. Teferi)

\section{To cite this article:}

Teklay Abebe Teferi, Muruts Legesse Wubshet. Prevalence and Intensity of Economically Important Fungal Diseases of Sorghum in South Tigray, Ethiopia. Journal of Plant Sciences. Vol. 3, No. 2, 2015, pp. 92-98. doi: 10.11648/j.jps.20150302.18

\begin{abstract}
Production and productivity of sorghum is highly threatened by different diseases in South Tigray, Ethiopia. However, the importance of each disease has not been assessed and well profiled to sound management strategy. To determine the occurrence and intensity of diseases survey was carried out in two major sorghum growing districts of South Tigray in 2014 cropping season. Results indicated that $93.7 \%, 84.8 \%, 88.6 \%, 37 \%$ and 58\% of sorghum fields were infected by anthracnose, leaf blight, long smut, head and loose smuts, and downy mildew, respectively. This indicated that sorghum is suffered from complexes of diseases. The incidence and severity of the former diseases were $69.9 \%$ and $53.01 \%, 55.9 \%$ and $38.7 \%, 23 \%$ and $77.2 \%, 1.9 \%$ and $71.7 \%$, and $43.6 \%$ and $41 \%$, respectively. Most of the cultivated farmers' cultivars sown were susceptible at least to one disease putting large area of sorghum production at threat. Therefore, holistic and cumulative integrated approach is required to manage the complex diseases in the surveyed areas.
\end{abstract}

Keywords: Diseases, Intensity, Prevalence, Sorghum

\section{Introduction}

Sorghum (Sorghum bicolar L. Moench) is one of the most important cereal crops supporting the lives of millions of people across the globe and particularly in the developing world. Sorghum is known for withstanding harsh environmental conditions including high temperature, moisture deficit and water stagnation [22]. The most important sorghum producers are the United State, Nigeria, India, Sudan, Ethiopia, Burkina Faso, China, Tanzania and Niger [8]. In Ethiopia, sorghum is among the leading cereal crops contributing a major role in achieving food security. It covers an area of over 1.7 million ha with annual production of more than 3.6 million tones. Sorghum stands first both in area coverage and production in Tigray region with annual coverage and production of about 208, 390 ha and over 0.5 million tone, respectively. The national and regional productivity of the crop is not more than $2.2 \mathrm{t} / \mathrm{ha}$ and $2.5 \mathrm{t} / \mathrm{ha}$, respectively [4]. Grain sorghum yields are especially low in Eastern Africa countries as compared to yields in the United States (4.4 t/ha) and well below the genetic potential [19].

Sorghum production in the world including Ethiopia is affected by different biotic and abiotic constraints. Of the biotic stresses, diseases caused by different fungal pathogens play significant role in curtailing its production. The major diseases that affect sorghum include Turcicum leaf blight, (Exserohilum turcicum), downy mildew (Peronoscleropora sorghi), anthracnose (Colletotrichium sublineolum Henn.) [6] and sorghum smuts (covered kernel smut (Sporisorium sorghi Ehrenberg (Link), loose smut (Sphacelotheca cruenta (Kuhn), and long smuts (Tolyposporium entrenbargii (Kuhn)) [19]. In Ethiopia, anthracnose, smuts, grain mold, downy mildew, charcoal rot and few others are important diseases, which are now considered as one of the most destructive diseases of sorghum in most the major growing regions of the country [3,7]. These diseases affects at different parts and stages of the crop that significantly reduce its productivity.

Assessment of the incidence and severity of plant diseases is important to determine the geographic distribution and status of the disease throughout a region in order to prioritize research responsive to the situation. To get an accurate picture on the status of any disease, such studies, should give due consideration to the impact of geophysical and associated climatic and edaphic variations between regions. However, most of the studies do not provide quantitative measurement in terms of disease severity in Tigray. On the other hand, such information is of paramount importance as it can be related to yield loss and hence economic impact of the disease $[12,19]$. Therefore, the objective of this survey was 
to determine the geographic distribution, incidence and severity of sorghum diseases in the major growing districts of South Tigray, Ethiopia.

\section{Materials and Methods}

\subsection{Area Description}

Tigray forms the northernmost reaches of Ethiopia and is located between $36^{\circ}$ and $40^{\circ}$ east longitude and $12.15^{\circ}$ and $14^{\circ} 57^{\prime}$ north latitude. The region has six administrative zones, of which, South zone is among the major sorghum producing areas of the region [4]. The survey program covered the most important sorghum growing districts of Raya valley (RayaAlamata and Raya-Azebo) in South Tigray (Figure 1). It is bordered by Hintalo Wajerat district to the north, Afar Region State to the east, Enda-Mekoni and Ofla district to the west and Amhara Region State to the south [20].

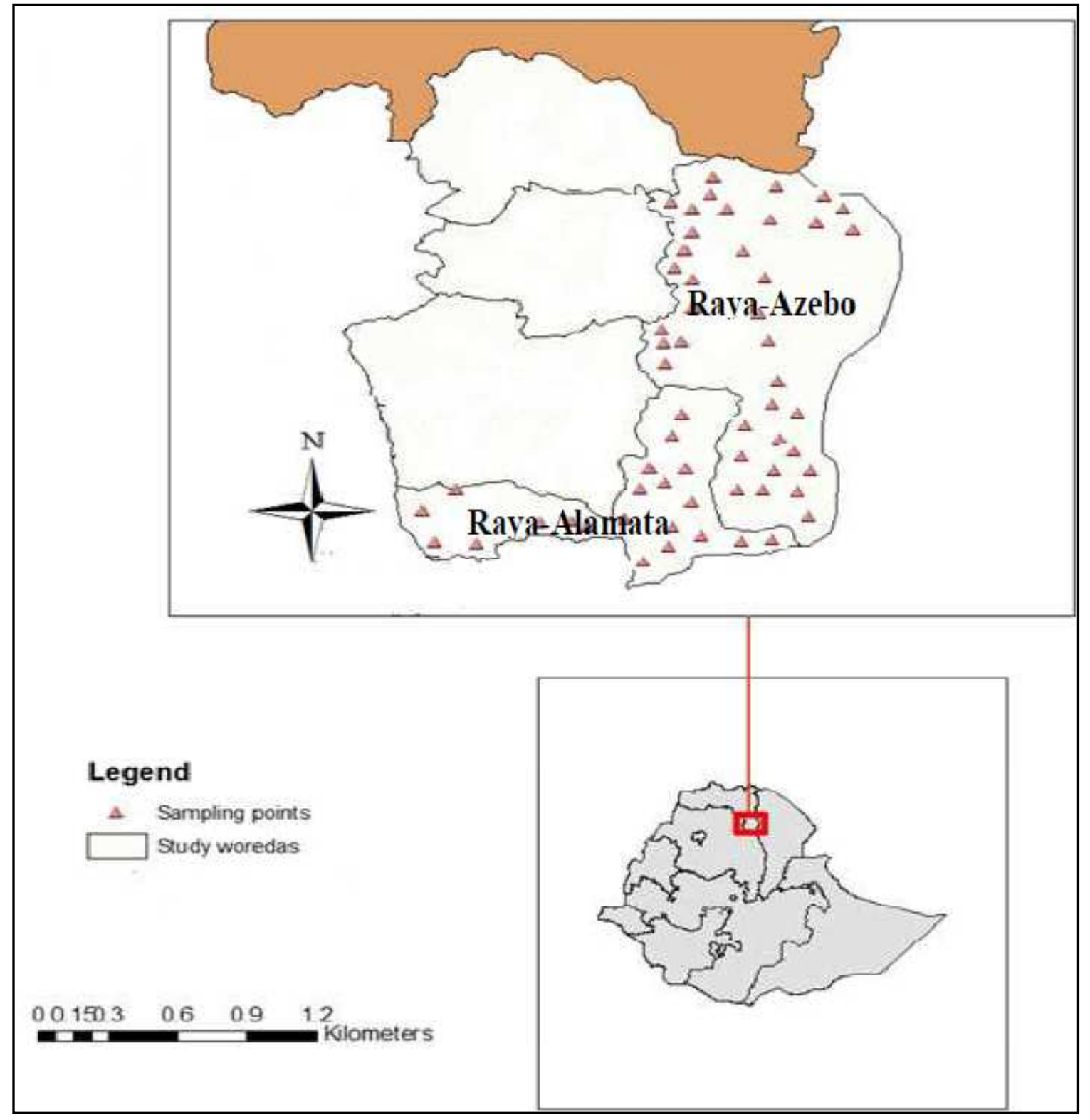

Figure 1. Map of Ethiopia showing sorghum surveying districts in South Tigray

\subsection{Disease Assessment}

The survey was carried out in 2014 main cropping season in South Tigray. It was made following the main roads and accessible routes in each survey district, and in each available sorghum field, stops were made at $5 \mathrm{~km}$ intervals based on vehicle odometers. A total of 15 peasant associations were assessed in both districts. At least three samples were assessed at each stop within the field depending on the farm size. During the survey, the sorghum crop was between early dough and hard dough stage in most of the fields, although there were some fields with sorghum at maturity stage. For each disease incidences were assessed as the percentage of sorghum plants in a field showing visible symptoms out of 20 randomly selected plants. Furthermore, the severities were 
determined as average leaf area covered by symptoms for 510 randomly selected diseased plants per stop/sample for foliar diseases and head damage for smuts. For foliar diseases, severity was assessed on a 1 to 9 scale where $1=$ no disease, $2=$ disease affecting 1 to $4 \%$ area of top 5 leaves, $3=5$ to $9 \%, 4=10$ to $19 \%, 5=20$ to $29 \%, 6=30$ to $44 \%, 7=45$ to $59 \%, 8=60$ to $75 \%$, and $9=>75 \%$ of leaf area affected [19]. In addition, smuts severities were scored considering the average of all plants using modified severity rating scale as used by [10] as follows: 1, no infected florets; $2,<10 \%$ infected florets; 3, 11-20\% infected florets, 4, 21-29\% infected florets; 5, 30-14\% infected florets; 6, 42-52\% infected florets; 7, 53-63\% , infected florets; 8, 64-74\% infected florets; and 9,> 75\% infected florets.

\section{Results and Discussion}

\subsection{The Prevalence, Incidence and Severity of Sorghum Diseases}

Subsistence farmers grew most of the sorghum surveyed under low-input cropping systems with long maturing local cultivars (6-8 months). Most of the sorghum planted fields surveyed were ranged from 0.25 to 0.5 ha depending on the land holding of each farmer. Conditions of the sorghum fields varied from well maintained to very poorly maintained farms. During the assessment farmers were able to identify smuts in general without naming the types (such as head smut, loose, long) but for the remaining foliar diseases they named as diseases without recognizing the specific names. Some farmers were mistakenly associated severe leaf disease symptoms with natural signs of crop maturity as well as winds. This study provides the quantitative report on the prevalence and intensity of sorghum diseases in South Tigray, Ethiopia. Accordingly, three leaf diseases; anthracnose, leaf blight and downy mildew and three smuts (covered head smut, long smut and loose smut) were the dominant diseases both in distribution and intensities (Table 1). In addition, rust was found at low frequency in Raya-Azebo district. This indicated that the seriousness of the damage caused by the fungal pathogens where sorghum is grown. Among which, sorghum anthracnose was epiphytotically appeared in all the survey routes putting a considerable sorghum production areas at jeopardy. The overall prevalence of anthracnose was $93.7 \%$. Of which, about $68.1 \%$ of the fields were sustained maximum possible prevalence $(100 \%)$ of the disease (Table 1). The prevalence of the remaining few fields varied from $75 \%$ to $84.6 \%$. This indicated the disease was among the destructive diseases during the season. Similarly, the incidence of anthracnose was reached maximum in most sorghum fields. All peasant associations exhibited $100 \%$ incidence in their many fields. The mean incidence of anthracnose was $100 \%$ in 27 fields of the seven peasant associations in both districts. The mean incidence of the disease was between $10 \%$ and $84.6 \%$ for eight peasant associations. The seriousness of anthracnose was explained by the damage (severity) exhibited on the plant. The peak severity $(100 \%)$ of the disease was registered at eight peasant associations. Similarly, two peasant associations (Selambakalsi and Hadiskigni) exhibited maximum possible mean severity $(100 \%)$. The mean severity of the anthracnose disease for the remaining peasant associations varied from $10 \%$ to $95 \%$. Generally, the overall severity of the disease was $53.01 \%$ (Table 1). As a result, farmers are frustrated by the nature and epidemics of the disease during the season. Previous studies revealed that this disease was listed among the leading diseases causing significant yield loss in different sorghum growing areas in Ethiopia [3, 5, and 7]. Chala et al., [5] reported that anthracnose had moderate to severe epidemics in the major sorghum growing areas of Ethiopia. Similarly, the results of this study confirmed the observations of [9], who listed these diseases as constraints to sorghum production in east African countries including Ethiopia. Furthermore, association of severe sorghum anthracnose infection with low and intermediate altitude areas is most probably attributed to the prevailing weather conditions as most areas with intermediate to high temperature. According to Ali and Warren, [2], Thomas, [26], and Hess et al., [11], more intense sorghum anthracnose is associated with high temperature and relative humidity. During the growing season, the occurrence of unseasonal rainfall during the flowering and dough stage coupled with high to moderate temperature $\left(10-27^{\circ} \mathrm{C}\right)$ encouraged the development of the disease. In addition, the high variability of the pathogen populations made most sorghum fields without tolerance [27].

The leaf blight was among the widely distributed and important diseases during the survey season. It was epidemically observed. The distribution of leaf blight was higher in almost all sorghum growing areas of the RayaAlamata and Raya-Azebo districts. About 54 fields within eight peasant associations sustained $100 \%$ of prevalence in both districts (Table 1). Raya-Alamata district was highly affected by leaf blight compared to Raya-Azebo district. All peasant associations were affected by the disease except Hawelti which was nonexistent. Ten out of 15 peasant associations sustained $100 \%$ diseases incidence. Similarly, the severity of leaf blight was significant in considerable locations during season. The mean severity of leaf blight was $100 \%$ in seven peasant associations. Likewise, the severity of the disease was higher on number of fields. The mean incidence ranged from $5 \%$ in Fachagama as high as $100 \%$ in Selambikalsi peasant associations. The favorable environmental conditions coupled with cultivation of susceptible sorghum cultivars worsened the problem to maximum. Disease epidemics are favoured by high rainfall and relative humidity, moderate temperatures, and the presence of large amounts of inoculums. In addition, the high intensity of the disease could be due to the availability of different races or pathogen population for leaf blight $[14,23]$. This study is in line with previous result that leaf blight was among the important diseases in all sorghum growing environments of the country [5]. Generally, the prevalence and intensity of most of the foliar diseases was high in Raya -Alamata compared to Raya-Azebo district. The most possible reason could be due to the disparity in environmental condition, production systems 
and practices and the variety grown.

Table 1. Percentage prevalence, incidence and severity of anthracnose and leaf blight diseases in Raya valley in 2014 cropping season.

\begin{tabular}{|c|c|c|c|c|c|c|c|}
\hline \multirow{3}{*}{ Districts } & \multirow{3}{*}{ Peasant association } & \multirow{3}{*}{ Field inspected } & \multicolumn{5}{|l|}{ Anthracnose } \\
\hline & & & \multirow{2}{*}{ Prevalence (\%) } & \multicolumn{2}{|c|}{ Incidence (\%) } & \multicolumn{2}{|c|}{ Severity (\%) } \\
\hline & & & & Range & Mean & Range & Mean \\
\hline \multirow{6}{*}{ Raya-Alamata } & Gerjelle & 5 & 80 & $0-100$ & 62 & $50-100$ & 48 \\
\hline & Kulugizelemlem & 7 & 100 & 100 & 100 & $50-100$ & 75.7 \\
\hline & Limat & 4 & 100 & $10-100$ & 57.5 & $10-80$ & 20 \\
\hline & Selambiklasi & 4 & 100 & 100 & 100 & 100 & 100 \\
\hline & Tao & 13 & 84.6 & $0-100$ & 84.6 & $20-100$ & 56.1 \\
\hline & Waja-Timuga & 6 & 100 & 100 & 100 & $10-100$ & 55 \\
\hline \multirow{9}{*}{ Raya-Azebo } & Bala & 4 & 100 & 100 & 100 & $50-100$ & 82.5 \\
\hline & Chercher & 3 & 100 & 10 & 10 & 100 & 10 \\
\hline & Fachagama & 2 & 100 & 100 & 100 & $90-100$ & 95 \\
\hline & Genete & 8 & 75 & $0-100$ & 18.1 & $5-50$ & 11.9 \\
\hline & Hade-Alga & 2 & 100 & 100 & 100 & $40-60$ & 50 \\
\hline & Hawelti & 5 & 100 & $10-50$ & 30 & $5-10$ & 11 \\
\hline & Hadiskegni & 10 & 100 & 100 & 100 & 100 & 100 \\
\hline & Tsigea & 5 & 100 & $10-100$ & 36 & $5-20$ & 10 \\
\hline & Wargiba & 1 & 100 & 50 & 50 & 70 & 70 \\
\hline Total/mean & & 79 & 93.7 & $0-100$ & 70 & $5-100$ & 53.01 \\
\hline
\end{tabular}

Table 1. Continue.

\begin{tabular}{|c|c|c|c|c|c|c|c|}
\hline \multirow{3}{*}{ Districts } & \multirow{3}{*}{ Peasant association } & \multirow{3}{*}{ Field inspected } & \multicolumn{5}{|l|}{ Leaf blight } \\
\hline & & & \multirow{2}{*}{$\begin{array}{l}\text { Prevalence } \\
(\%)\end{array}$} & \multicolumn{2}{|c|}{ Incidence (\%) } & \multicolumn{2}{|c|}{ Severity (\%) } \\
\hline & & & & Range & Mean & Range & Mean \\
\hline \multirow{6}{*}{ Raya-Alamata } & Gerjelle & 5 & 100 & 100 & 100 & $40-100$ & 72 \\
\hline & Kulugizelemlem & 7 & 100 & 100 & 100 & $20-100$ & 71.4 \\
\hline & Limat & 4 & 100 & 100 & 100 & $20-50$ & 32.5 \\
\hline & Selambiklasi & 4 & 100 & 100 & 100 & $10-100$ & 70 \\
\hline & Tao & 13 & 100 & 100 & 100 & $50-100$ & 65.4 \\
\hline & Waja-Timuga & 6 & 100 & 100 & 100 & $10-100$ & 55 \\
\hline \multirow{9}{*}{ Raya-Azebo } & Bala & 4 & $0-75$ & -100 & 40 & $20-60$ & 32.5 \\
\hline & Chercher & 3 & 33.3 & $0-30$ & 10 & 10 & 10 \\
\hline & Fachagama & 2 & 50 & $0-10$ & 5 & 10 & 10 \\
\hline & Genete & 8 & 62.5 & $0-100$ & 18.8 & $10-50$ & 12.5 \\
\hline & Hade-Alga & 2 & 50 & $0-100$ & 50 & 30 & 30 \\
\hline & Hawelti & 5 & 0 & 0 & 0 & 0 & 0 \\
\hline & Hadiskegni & 10 & 100 & 100 & 100 & $5-100$ & 65 \\
\hline & Tsigea & 5 & 40 & $0-10$ & 4 & $10-10$ & 10 \\
\hline & Wargiba & 1 & 100 & 10 & 10 & 10 & 10 \\
\hline Total/mean & & 79 & 84.8 & $0-100$ & 55.9 & $10-100$ & 39 \\
\hline
\end{tabular}

Sorghum suffers a lot from smuts during the assessment. Three distinct smut diseases of sorghum were recognized during the survey. They were the covered head smut induced by the fungus Sporisorium sorghi, loose smut induced by Sporisorium holci-sorghi and long smut attributed to the fungus described as Tolyposporium ehrenbergii. Among which, long smut was the most commonly occurring and important disease during the survey. It was observed 14 peasant associations except at Gerjelle (Table 2). The prevalence of the disease was reached $100 \%$ in 12 peasant associations. This indicated that the disease was present where sorghum is grown. Similar reports indicated that smuts especially, loose, head smut and long smut was the challenging biotic factors to sorghum production in many parts of Ethiopia [17]. This is because of the occurrence of favorable environment (which usually have intermediate to high temperature and erratic rain fall pattern) responsible for the rapid development of disease. The incidence of long smut was ranged from $5 \%$ in most fields to $100 \%$ in two peasant associations. Similarly, the mean incidence of most fields was below $15 \%$. The severity of smuts were exhibited by the infection head or panicle caused up to complete crop failure. As a result, most of fields sustained $100 \%$ severity (Table 2). The other smuts group attacking sorghum were covered and loose smuts, but at low prevalence as compared to long smut. The prevalence of covered and loose smuts together was reached $100 \%$ in two peasant associations (Table 2). The incidence of covered kernel smut varies from place to place but in Ethiopia, it was estimated to be about 50\% [16, 25]. According to Sisay et al., [21] for higher covered smut incidence, optimum temperature of $25^{\circ} \mathrm{C}$ and half moistened soil during planting are more important than other factors. Smuts are among the damaging diseases of sorghum in Ethiopia [17, 24 and 25]. The use of local cultivars with lower quality might be aggravated the epidemiology of smut. In addition, prevailing weather is another important factor that influences the incidence and severity of plant diseases [13]. Moreover, the movement of spores was facilitated by 
wind within the farm. In addition to yield reduction, it also adversely affected the quality of grains, when the black masses of chlamydospores contaminated the grain at the time of harvesting and threshing.

Sorghum downy mildew was among the widely occurred fungal diseases in all survey routs in 2014 main cropping season. It was observed in 10 fields out of 15 peasant associations. It was among the commonly observed of the leaf disease, being observed in $66.7 \%$ of fields. The incidence of the disease within fields was generally high, with a majority of fields having an incidence range of $10 \%$ to $100 \%$. A considerable sorghum fields were severely attacked by downy mildew with maximum possible severity of $100 \%$. Similarly, the mean severity of downy mildew ranged from lowest $(2.5 \%)$ at Genete as high as $80 \%$ in two peasant association (Tao and Hadiskigni) (Table 2). This study is in line with previous result that downy mildew was among the important diseases in all sorghum growing environments of the country [5]. Generally, the prevalence and intensity of most of the foliar diseases was high in Raya -Alamata compared to Raya-Azebo district due to the environmental condition divergence. In contrast, 27 fields were free from downy mildew due to variability in climatic condition, management practices, and unavailability of initial inoclum.

Table 2. Percentage prevalence, incidence and severity of smuts and downy mildew diseases in Raya valley in 2014 cropping season.

\begin{tabular}{|c|c|c|c|c|c|c|c|}
\hline \multirow{3}{*}{ Districts } & \multirow{3}{*}{ Peasant association } & \multirow{3}{*}{ FI } & \multicolumn{5}{|c|}{ Long smut } \\
\hline & & & \multirow{2}{*}{ Pre } & \multicolumn{2}{|c|}{ Incidence } & \multicolumn{2}{|c|}{ Severity (\%) } \\
\hline & & & & $\mathbf{R}$ & $\mathbf{M}$ & $\mathbf{R}$ & M \\
\hline \multirow{5}{*}{ Raya-Alamata } & Gerjelle & 5 & 0 & 0 & 0 & 0 & 0 \\
\hline & Kulugzelemlem & 7 & 100 & $5-100$ & 21 & $10-100$ & 67.1 \\
\hline & Limat & 4 & 100 & $5-5$ & 5 & $100-100$ & 100 \\
\hline & Selambiklasi & 4 & 100 & $5-5$ & 5 & $100-100$ & 100 \\
\hline & Tao & 13 & 76.9 & $0-20$ & 5 & $50-100$ & 80 \\
\hline \multirow{8}{*}{ Raya-Azebo } & Bala & 4 & 100 & $5-10$ & 100 & 100 & 100 \\
\hline & Chercher & 3 & 100 & $10-10$ & 10 & $20-100$ & 73.3 \\
\hline & Fachagama & 2 & 100 & $10-10$ & 10 & $50-50$ & 50 \\
\hline & Genete & 8 & 100 & $5-100$ & 48 & $50-100$ & 73.8 \\
\hline & Hade-Alga & 2 & 50 & $0-10$ & 5 & 100 & 100 \\
\hline & Hawelti & 5 & 100 & $5-50$ & 14 & $25-100$ & 56 \\
\hline & Hadiskigni & 10 & 100 & $5-30$ & 13 & $100-100$ & 100 \\
\hline & Wargiba & 1 & 100 & 80 & 80 & 35 & 35 \\
\hline Total/mean & & 79 & 88.6 & $0-100$ & 23 & $10-100$ & 77.2 \\
\hline
\end{tabular}

Table 2. Continue.

\begin{tabular}{|c|c|c|c|c|c|c|c|c|c|c|c|}
\hline \multirow{3}{*}{ Districts } & \multirow{3}{*}{ Peasant association } & \multicolumn{5}{|c|}{ Covered head and loose smuts } & \multicolumn{5}{|c|}{ Downy mildew } \\
\hline & & \multirow{2}{*}{ Pre } & \multicolumn{2}{|c|}{ Incidence } & \multicolumn{2}{|c|}{ Severity $(\%)$} & \multirow{2}{*}{ Pre } & \multicolumn{2}{|c|}{ Incidence } & \multicolumn{2}{|c|}{ Severity } \\
\hline & & & $\mathbf{R}$ & M & $\mathbf{R}$ & M & & $\mathbf{R}$ & M & $\mathbf{R}$ & $\mathbf{M}$ \\
\hline \multirow{5}{*}{$\begin{array}{l}\text { Raya- } \\
\text { Alamata }\end{array}$} & Gerjelle & 0 & 0 & 0 & 0 & 0 & 80 & $0-100$ & 70 & $20-100$ & 42 \\
\hline & Kulugzelemlem & 14 & $0-5$ & 0.7 & $20-20$ & 20 & 0 & 0 & 0 & 0 & 0 \\
\hline & Limat & 100 & $5-5$ & 5 & 100 & 100 & 100 & $10-100$ & 77.5 & $10-20$ & 15 \\
\hline & Selambiklasi & 100 & $5-5$ & 5 & 100 & 100 & 100 & 100 & 100 & $10-100$ & 70 \\
\hline & Tao & 15 & $0-5$ & 0.4 & $50-100$ & 11 & 100 & 100 & 100 & $30-100$ & 80 \\
\hline \multirow{8}{*}{$\begin{array}{l}\text { Raya- } \\
\text { Azebo }\end{array}$} & Bala & 0 & 0 & 0 & 0 & 0 & 0 & 0 & 0 & 0 & 0 \\
\hline & Chercher & 100 & $0-5$ & 3.3 & 100 & 100 & 0 & 0 & 0 & 0 & 0 \\
\hline & Fachagama & 50 & $0-5$ & 5 & 100 & 100 & 100 & 100 & 100 & $40-50$ & 45 \\
\hline & Genete & 25 & $0-5$ & 1.7 & $20-100$ & 60 & 12 & $0-50$ & 6.3 & $20-20$ & 2.5 \\
\hline & Hade-Alga & 0 & 0 & 0 & 0 & 0 & 0 & 0 & 0 & 0 & 0 \\
\hline & Hawelti & 60 & $0-5$ & 4.2 & $30-50$ & 26 & 20 & $0-20$ & 4 & $10-10$ & 10 \\
\hline & Hadiskigni & 0 & 0 & 0 & 0 & 0 & 100 & 100 & 100 & $50-100$ & 80 \\
\hline & Wargiba & 0 & 0 & 0 & 0 & 0 & 0 & 0 & 0 & 0 & 0 \\
\hline Total/mean & & 37 & $0-5$ & 1.9 & $20-100$ & 71.7 & 58 & $0-100$ & 43.6 & $10-100$ & 41 \\
\hline
\end{tabular}

FI-fields inspected, Pre-prevalence, R-range, M-mean

\subsection{The Response of Sorghum Cultivars}

The infection level of host plants varied depending on the susceptibility level of each cultivar, the management practiced and the environmental conditions in a specific environment. Local cultivars were the most commonly grown in the study area. Farmers preferred local cultivars due to the fact that higher yield and long stalk for their house construction and feed value [15]. However, these cultivars are long maturing up to eight months difficult to grow under low and erratic rainfall condition. About $94.9 \%$ of the cultivated area was covered by the local medium to long maturing cultivars. The remaining few varieties was present on demonstrations basis at research sites and farmer training 
centers at lower frequency. Generally the local cultivars were found susceptible to most diseases occurred during the season. As a result, most sorghum fields were leaved without harvesting. The prevalence of anthracnose, leaf blight, downy mildew and smuts on local cultivars ranged from 97.1\%$100 \%, \quad 73.9 \%-100 \%, \quad 26.1 \%-93.8 \%$ and $75 \%-100 \%$, respectively. Similarly, the incidences of these diseases were higher on local cultivars (Table 3). The mean severities for the foliar diseases were varied from $10-67.5 \%, 73.9-100 \%$, and 33\%-60\%, respectively. The cultivar Degalit was the longest maturing (8 months) [15] and found susceptible to most identified diseases. This was followed by the relatively short maturing cultivar Abo-Ere (6 months) with relative susceptible. The medium maturing cultivars such as Kodem and Jamuye were susceptible to most diseases but with less intensity than Abo-Ere and Degalit. The higher epidemics or epiphytotic of anthracnose was uncommon despite the frequent occurrence from lowered to moderate infection leaves. Farmers growing the local cultivars were frustrated by the unusual epidemics of anthracnose, leaf blight and downy mildew makes wiped-out sorghum fields without tolerance during the year. In addition, the mono-cropping systems in the area could be contributed to disease pressure in positive or negative ways [1]. The early maturing improved varieties (3-4 months) [18] were found susceptible to leaf blight and downy mildew exhibited mostly $100 \%$ prevalence and incidence. Most of the local cultivars and one improved variety were found susceptible to smuts. This study revealed that almost all farmers preferred their own local cultivars for many reasons such as high yielding ( $>6 \mathrm{t} / \mathrm{ha})$, having long stalk used to feed for livestock and used for construction of different houses as well as fences. However, these local cultivars are long maturing (6-8 months) [15] and susceptible to most diseases. Therefore, introduction of high yielding improved varieties with acceptable disease resistance from international and national nurseries and awareness creation for farmers to protect against these diseases is of a great concern.

Table 3. The percent prevalence, mean incidence and mean severity of major diseases on sorghum cultivars.

\begin{tabular}{|c|c|c|c|c|c|c|c|c|c|c|c|c|c|}
\hline \multirow{2}{*}{ Cultivars } & \multirow{2}{*}{$\begin{array}{l}\text { Total } \\
\text { Fields } \\
\end{array}$} & \multicolumn{3}{|c|}{ Anthracnose } & \multicolumn{3}{|c|}{ Leaf blight } & \multicolumn{3}{|c|}{ Downy mildew } & \multicolumn{3}{|c|}{ Long Smut } \\
\hline & & Pre & Inc & Sev & Pre & Inc & Sev & Pre & Inc & Sev & Pre & Inc & Sev \\
\hline Abo-Ere/Ganno* & 34 & 97.1 & 76.3 & 59.7 & 79.4 & 59.7 & 55.2 & 26.5 & 21.2 & 46.7 & 100 & 16.03 & 80.3 \\
\hline Birhan *** & 1 & 0 & 0 & 0 & 100 & 100 & 80 & 100 & 100 & 60 & 100 & 20 & 100 \\
\hline Degalit* & 16 & 100 & 95 & 67.5 & 100 & 100 & 70 & 93.8 & 88.13 & 60 & 75 & 3.8 & 91.7 \\
\hline Gobiye*** & 2 & 50 & 5 & 10 & 100 & 100 & 50 & 100 & 75 & 40 & 0 & 0 & 0 \\
\hline Jamuye ** & 1 & 100 & 30 & 10 & 0 & 0 & 0 & 0 & 0 & 0 & 100 & 50 & 80 \\
\hline Melkam *** & 1 & 0 & 0 & 0 & 100 & 100 & 40 & 100 & 100 & 20 & 0 & 0 & 0 \\
\hline
\end{tabular}

*Long maturing local cultivars, $* *$ - medium maturing local cultivars, $* * *$ - early maturing improved varieties

Pre-prevalence, Sev-severity, Inc-incidence

In general, anthracnose, leaf blight, downy mildew and smuts (long, covered head and loose) were among the destructive diseases during 2014 cropping season in both districts. The occurrence and the infection of more than one disease for a single plant exacerbated the yield diminution to maximum and wiped-out sorghum local cultivars without tolerance. Therefore, producers can have an impact on the severity of these diseases by choosing from a number of management strategies including host plant resistance, cultural practices (adjusting planting date, use of disease free seeds, rotation) and judicious use of fungicides [1]. However, using genetically resistant wheat varieties is panacea, the ultimate universal answer, cost effective and environmentfriendly mode of protection [1]. Furthermore, the use of gene pyramiding in variety development has paramount importance for such diseases for a broad resistance along with periodic disease monitoring and surveillances responsive for the pathogen variation or races. It is also very important to use integrated management tactics and risk forecasting that operate on different aspects of the disease etiology, such that they complement each other and can be applied together in farmers' fields collectively to provide farmers with maximum economic return.

\section{Conclusion}

Sorghum production is suffered from different fungal diseases mainly anthracnose, leaf blight, downy mildew and smuts. The combination effect of these complex diseases caused up to complete annihilation of the crop. The long and medium maturing local cultivars were found susceptible compared to the early maturing improved varieties. Therefore, development of integrated diseases management strategies needs due emphasis for sustainable sorghum production.

\section{Acknowledgement}

We would like to thank to the crop research team at the Alamata agricultural research center for their support during the entire period of the study. Our great gratitude also goes to the Tigray Agricultural Research Institute (TARI) for the coordination of the research region wise.

\section{References}

[1] Agrios, G. N. 2005. Plant Pathology, $5^{\text {th }}$ ed. Department of Plant Pathology. University of Florida. pp 125-170. 
[2] Ali, M.E.K., Warren, H.L., 1987. Physiological races of Colletotrichum graminicola on sorghum. Plant Dis., 71: 402404.

[3] Bekele E., 2006. Experience with Management of Major Plant Diseases in Ethiopia. In: Facilitating the Implementation and Adoption of Integrated Pest Management (IPM) in Ethiopia, Bekele, E., Azerefegne, F., Abate, T.,(eds). Drylands Coordination Group Procesdings No. 17 Feb. 02, 2006. Melkssa ARC, EIAR, Ethiopia.25-34.

[4] Central Statistics Agency (CSA), 2013. Crop Production Forecast Sample Survey for the year 2013/2014. Report on Area and Crop Production forecast for Major Crops (For Private Peasant Holding, Meher Season) Addis Ababa, Ethiopia, 7-10.

[5] Chala, A., Brurberg, M.B., Tronsmo, A.M., 2010. Incidence and Severity of Sorghum Anthracnose in Ethiopia. Plant Pathology Journal, 9: 23-30

[6] DeVries, J., Toeniessen, G., 2001. Securing the harvest Biotechnology, Breeding and seed system for Africa Crops. CABI publishing.

[7] Eshte,Y., Mitiku, M., Shiferaw, W., 2014. Assessment of important plant disease of major Crops (Sorghum Maize, common bean, coffee, Mungbean, Cowpea) in South Omo and Segen Peoples Zone of Ethiopia. Sci. Agri. 8(2), 91-94.

[8] FAO STAT., 2009. Production stat: crops. FAO statistical databases, http://faostat.fao.org.

[9] Guiragossian, V., 1986. Sorghum production constraints and research needs in eastern Africa. Pages 28-46 in: Proc. Regional Workshop Sorghum Millet Improvement in Eastern Africa, 5th. EARSAM, Nairobi, Kenya

[10] Gwary, D.M, Bilya, B.S, Adakole, A.C., 2001. Evaluation of pearl millet genotypes for resistance to smut (tolyposporium penicilliarie BERF) in Northeastern Nigeria. Arid Agric. 12, 81-84.

[11] Hess, D.E., Bandyopadhyay, R., Sissoko, I., 2002. Pattern analysis of sorghum genotype $\mathrm{H}$ environment interaction for leaf, panicle and grain anthracnose in Mali. Plant Dis., 86, $1374-1382$.

[12] Jeger, M.J., 1990. Mathematical analysis and modeling of spatial aspects of plant disease epidemics. Pages 53-88 in: Epidemics of Plant Diseases: Mathematical Analysis and Modeling. J. Kranz, ed. Springer-Verlag, New York.

[13] Kranz, J. and J. Rotem, 1987. Experimental Techniques in Plant Disease Epidemiology. Springer-Verlag, Berlin, pp: 299.

[14] Leonard, K.J., Levy, Y. and Smith, D.R. 1989. Proposed nomenclature for pathogenic races of Exserohilum turcicum on corn. Plant disease 73:776-777.
[15] Meles, K., Nigussie, G., Belay, T., Manjur, K. 2009. Seed System Impact on Farmers' income and Crop Biodiversity in the Drylands of Southern Tigray, Drylands Coordination Group Report No. 54, 1-50.

[16] Mengestu, H., 1982. Diseases of sorghum at some locations in Ethiopia. Ethiopian J. Agric. Sci., 4(1): 45-53.

[17] Merkuz, A., Getachew, A., 2012. Distribution and severity of sorghum covered kernel smut in North Western Ethiopia. International Journal of Current Research. 4 (4), .041-045.

[18] MoA (Ministry of Agriculture) 2011. Animal and plant health regulation directorate. Crop variety register. Issue No. 14. Addis Ababa, Ethiopia.

[19] Ngugi, H.K., King, S.B., Abayo, G.O., Reddy, Y.V.R., 2002. Prevalence, incidence, and severity of sorghum diseases in western Kenya. Plant Dis. 86, 65-70.

[20] REST (Relief Society of Tigray), 1996. Raya Valley Development Study Project, Phase I (Reconnaissance report). Relief Society of Tigray, Mekelle, Ethiopia

[21] Sisay, A., Abebe, F., Wako K., 2012. Evaluation of three potential botanicals against sorghum covered smut (Sphacelotheca sorghi) at Bako, Western Oromia Ethiopia Bako Agricultural Research Center Bako, Ethiopia. African J Plant Sci. 6(8):226-231,

[22] Sleper, D.A., and Poehlman, J.M., 2006. Breeding field crops. $5^{\text {th }}$ Edn., Whily-Blackwell Publ., USA. Pp 424

[23] Tarumoto, I., Isawa, K. And Watanabe, K. 1977. Inheritance of leaf blight resistance in sorghum-sudangrass and sorghumsorghum hybrids. Japan Journal of Breeding 27(3):216-222.

[24] Tegene, S., Abdusalam, F., Legesse, F., 2013. Evaluation of Efficacy of different Disease Management Practices against sorghum covered smut (Sphacelotheca sorghi) at Fedis and Babile, Eastern Ethiopia. Research and Reviews: Journal of Agriculture and Allied Sciences, 3, 31-38.

[25] Teklemariam, W., 1985. A review of research on maize and sorghum disease in Ethiopia. In: Tsedake Abate (ed.). Proceeding of the First Ethiopian Crop Protection Symposium 4-7 Feb. 1985. IAR, Addis Ababa, Ethiopia, pp. 21-34.

[26] Thomas, M.D., 1992. Sorghum Diseases in Western Africa. In: Sorghum and Millet Diseases: A Second World Review, De Milliano, W.A.J., R.A. Frederiksen and G.D. Bengston (Eds.). International Crop Research Institute for the Semi-Arid Tropics, Patancheru, India, pp: 25-29.

[27] Valerio, H.M., Resende, M.A., Weikert-Oliveira, R.C.B., Casela, C.R., 2005. Virulence and molecular diversity in Collectotricum graminicola from Brazil. Mycopathologia 159: 449-459. 